FACTA UNIVERSITATIS

Series: Economics and Organization Vol. 14, N $\mathrm{N}^{\mathrm{o}} 3,2017$, pp. 281 - 289

https://doi.org/10.22190/FUEO1703281E

Preliminary Communication

\title{
CONCENTRATION EFFECT ON THE EFFICIENCY OF BANKING SECTOR IN THE REPUBLIC OF SERBIA
}

\author{
UDC 347.734:65.015.25(497.11)
}

\author{
Eva Erakovic ${ }^{*}$ \\ University of Niš, Faculty of Economics, Serbia
}

\begin{abstract}
For qualitative analysis of the effect of specific activities, such as banking, on other movements in this sector, precise measuring is needed. Due to the transformation of the banking sector in the Republic of Serbia, in a relatively short period of time, there has been a significant reduction in the number of banks and in increasing the concentration. On the other hand, the business efficiency has become a key factor for the survival of banks in the market. In this study, the concentration was measured by Herfindahl-Hirscham Index, while the degree of efficiency was determined by cost to income ratio. A linear correlation and regression analysis examined the relationship between the degree of concentration and the level of efficiency of Serbian banking sector in the time interval from 2008 to 2015, which confirmed the existence of a strong relationship between these variables.
\end{abstract}

Key words: concentration, efficiency, banking sector, Republic of Serbia

JEL Classification: D40, G21

\section{INTRODUCTION}

In the analysis of the market structures, the basic element is the concentration. It is believed that a particular branch, sector or industry is concentrated when a small number of participants control the majority of overall activities or resources. Every company or an individual market participant aims to increase their market share because there is a positive reciprocity between market share and profitability.

Increasing the concentration in certain sectors of the banking market can lead to undesirable market power of banks. Also, the accuracy and stability of the financial sector can variously affect the degree of the concentration and competition. The concentration of

Received February 28, 2017 / Revised April 25, 2017/ Revised July 07, 2017 / Accepted July 13, 2017

Corresponding author: Eva Eraković, "PhD student

University of Niš, Faculty of Economics, Trg kralja Aleksandra 11, Serbia

E-mail: evaerakovic89@yahoo.com 
several banks in the market indicates an unsuccessful bank competition and the inability of the market to prevent this phenomenon. This leads to improper functioning of the system and has a negative impact on the normal operation of banks. Today, the protection of the financial system health is one of the key objectives of banking supervision.

Changing business conditions in the market make constant pressure on banks to increase their income and to control their costs. Technological innovation in the form of improved communication and data processing, also, emphasizes the importance of efficiency. Numerous statistical studies have shown that the most efficient banks have significant cost savings and a competitive advantage compared to those with average or below average level of efficiency.

The subject of this research is to determine the relationship level between the concentration and efficiency in the banking sector of the Republic of Serbia, in the time interval from 2008 to 2015. For the purpose of the study, as a concentration indicator, Herfindahl-Hirschman Index was used, and as a measure of efficiency, cost to income ratio.

\section{MARKet CONCENTRATION IN THE BANKING SECTOR}

"Concentration, as an indicator of the degree to which the total production or sale in the market is in the hands of a small number of market participants, is the measure of the competition intensity. The high level of competition with the low level of concentration is healthy for each branch and the economy in general" (Stojanović et al., 2010, p. 58).

The concept of concentration is one of the basic elements in the analysis of market structure, i.e. market power in a particular industry, sector or branch. The concentration exists when there is a larger part of the total resources or activities under the supervision of a small part of the total number of units that supervise this resource, i.e. this activity. There are two factors of concentration: the absolute number of enterprises, which constitute one industry, and the relative size of companies in relation to the entire industry.

Concentrations can be: horizontal, vertical and conglomerate. In the banking sector, as a rule, concentrations are horizontal. These include connecting of competitors in a market who offer mutual substituent products and services. Affiliation, merging and acquisition of banks by more market-powerful banking institutions are the most visible aspect of concentrations in this area. However, due to strengthening of the banking sector, there has also been bank merging with other types of financial institutions which have offered different products and services, by which the banks expanded their range of products and services. These processes have resulted in a creation of large banks, i.e. "financial institutions that are so big that their activities represent a significant share in the payment system of a country, in the process of granting loans and in other financial services. The result is that any significant disruption in the operations of such institution has a serious impact on the financial market of that country. The consequence of this big to fail factor is that the country protects the business of such institutions and their customers in a way that does not guarantee the other market participants" (Petrović \& Ružić, 2001, p. 9).

As in other industries, the level of competition in the banking sector is essential to the production efficiency of banking services, product quality and level of innovation in the sector. Determining the degree of competition and concentrations in the banking sector and the relationship between these concepts represents the analytical and methodological issue. 
Numerous empirical studies have been devoted to this topic. Most studies reach the conclusion that the market conditions prevailing in banking sectors can be best characterized as naturally oligopolistic. This means that - in the long term - there is just room for a few viable banks. In this context, a highly concentrated banking sector is the logical outcome of market forces (Bikker \& Groeneveld, 1998, p. 3).

A group of authors Claessens, Demirguec-Kunt and Huizinga (2000) investigated the role of foreign banks and indicated that the entry of foreign banks makes the domestic banking system more efficient and reduces interest margins. Using data from the banks of 80 countries, they examined the effects of the bank concentration and their regulation on banks efficiency. They came to the conclusion that the concentration of banks has a negative and significant impact on the efficiency of the banking system, except in rich countries with welldeveloped financial systems. In addition, they consider that regulatory barriers of new banks entries, especially those relating to foreign banks, as well as implicit and explicit restrictions of the bank activities are associated with the lower level of bank margins. Their measure of bank efficiency, the net interest margin is not necessarily an indicator of the actual level of competitiveness on the market, but it can demonstrate other factors, such as market power and risk appetite. Claessens and Laeven (2003) examined the relationship between the type of market structure and net interest margin. Using data from banks and a customized version of methodology Panzar and Rosse, they assessed the degree of competition in the banking systems of fifty countries. Their results confirm that competitiveness helps determine the degree of efficiency, especially through the entry of foreign banks and the elimination of activity restrictions. Larger presence of foreign banks and smaller number of restrictive measures in the banking sector make the banking system more competitive. Also, the restrictions on entering commercial banks reduce competition, which indicates that the most important element of the competitiveness is the freedom of entry. They have not shown that the concentration of the banking sector is negatively correlated with competitiveness. On the contrary, their research proves that the banking system which is more concentrated is more competitive. The results show that a compromise had not to exist between higher and lower concentrated systems. A competitive system can be more important for ensuring the competitiveness of the system with a low concentration. In the study of rules governing the banking system, including input and output constraints, Barth, Caprio and Levine (2001) have come to the conclusion that stricter entry conditions have a negative impact on the bank efficiency, which results in increase of the interest margin and costs, while restrictions on participation of foreign banks lead to increased fragility of banks.

The theory provides conflicting forecasts about the relationship between regulations, concentration, institutions and bank efficiency. Many of these contradictions are the result of different beliefs about the causes of concentration. One common view holds that regulatory impediments to competition and monopolistic power create an environment in which a few powerful banks stymie competition with deleterious implications for efficiency (DemirguecKunt et al., 2003, p. 1). From that aspect, concentration is a useful signal for lack of competitiveness, and therefore for an inefficient market. The theory of "efficiency-structure" claims that more effective banks have lower costs and a higher market share (Demsetz, 1973). With this perspective, the competitive environment can produce concentrated and efficient banking systems. Enlargement, i.e. strengthening the concentration of banks should positively affect the entire economic system (Marinković, 2012). The arguments that support this claim are that big banks have a more efficient organization and management, and thus a greater potential for higher quality services. 
One of the most commonly used indicators is Herfindahl-Hirschman Index (HHI). It measures the concentration summing squares of market shares of all companies in an industry. The formula for calculating is:

$$
H H I=\sum_{i=1}^{n}\left(X_{i}^{2}\right)
$$

Where is $n$-the number of companies in the market, a $X$ - a share of $i$ company.

The advantage of Herfindahl-Hirschman Index is that it includes the value of market shares of all the companies of an industry and, by their squaring, it gives greater weight shares of larger companies. The value of HHI, theoretically, may be in the range of 0 to 10000 . In the case of monopoly, the Herfindahl-Hirschman Index value is 10000 , because the offer of the monopoly company equals the entire branch. In perfect competition, the offer of each company tends to 0 , so the value of this Index tends to 0 .

Table 1 Types of markets according to the values of Herfindahl-Hirschman Index

\begin{tabular}{ll}
\hline HHI value & Concentration level \\
\hline HHI $<1000$ & Non-concentrated (low concentrated) offer. \\
$1000 \leq \mathrm{HHI}<1800$ & Medium concentrated offer. \\
$1800 \leq \mathrm{HHI}<2600$ & High concentrated offer. \\
$2600 \leq \mathrm{HHI}<10000$ & Very high concentrated offer. \\
$\mathrm{HHI}=10000$ & Monopolistic concentrated offer. \\
\hline & Source:
\end{tabular}

By Herfindahl-Hirschman Index, the concentration of the banking sector in the time interval from 2008 to 2015 will be analyzed.

\section{EFFICIENCY OF THE BANKING SECTOR}

Comparing the financial systems and different countries and regions, Allen and Gale (2001) conclude that there is inherent inefficiency within the monopolistic power of banks, which may also adopt an excessively conservative approach while the competitive nature of markets tends to encourage innovation and growth-enhancing activities (Ferreira, 2012 , p. 7). In recent decades, banks have been operating in a very competitive environment, and in addition to size, capitalization, liquidity and other quantitative variables, they have been "forced" to take into account the efficiency as well. However, it should not be concluded that the efficiency is a new asset for the banking system. On the contrary, this variable has always been an asset for the banking system, but it has not been a priority, because the business conditions have been different than today. The structure, performance and function of the banking sector had to adapt to modern conditions, demanding a higher level of efficiency which is crucial for their survival and it can create a competitive advantage for them. An efficient banking sector is able to neutralize negative shocks and to contribute to the stability of the financial system. The performance of each bank is measured relative to what the best performance of a best practice bank on the efficient frontier would be expected to be if it faced the same exogenous conditions as the bank being measured (Berger, 2007, p. 122). 
There are three categories of efficiency: productive, cost and profit efficiency (Apergis \& Alevizopoulou, 2011, p. 330). The first type refers to the production based on given input parameters. The production plan is effective if there is a way to increase production with the same amount of inputs, i.e. it is not possible to produce the same amount with less inputs. The second type of efficiency measures the ability of banks to reduce costs at a given price of input parameters. In fact, this type of efficiency measures how close or far the costs of banks are from the banks with the best practice, producing the same amount in the same business conditions. If the costs of a bank are higher than the costs of the best bank practice, and that difference cannot be explained by any statistical noise, then, that bank is characterized as cost inefficient. Finally, profit efficiency measures the ability of banks to maximize profits given the prices of inputs and outputs. In fact, it implies maximizing production at a given level of expenditure.

In addition to the traditional way of measuring efficiency, there are two approaches that can be used to assess the efficiency of banks - the parametric approach and nonparametric approach. Both require the specification of a cost or production function or frontier, but former involves the specification and econometric estimation of a statistical or parametric function/frontier, while the non-parametric approaches provides a piecewise linear frontier by enveloping the observed data points (Drake \& Hall, 2003, p. 897). In general, both approaches analyze the best practices of production, cost or profit. A serious lack of the non-parametric approach is that it does not allow that there is any error in the data, and therefore assumes that the final assessment is solely because of inefficiencies.

In this paper, the concept of efficiency will be reflected cost to income ratio (C/I ratio). This indicator shows the ability of banks that, by achieved interest margin, as a major generator of profits, and other operating income, covers the part of business expenses arising mainly out of the credit-deposit operations themselves (Ljumović et al., 2011, p. 44). On the cost side, there are non-interest expenses, whose most important elements are gross earnings, depreciation expenses, tangible and intangible expenses and certain categories of expenditures that may arise on the basis of credit-deposit operations. In the denominator, there are incomes that pose a sum of net interest income and other operating incomes.

Based on the cost-to-income ratio investors have a clear picture of how efficiently the firm is being run - if it is lower, the bank will be more profitable. Also, changes in the ratio indicate potential problems: if the ratio rises from one period to the next, it means that costs are rising at a higher rate than income, which could suggest that the company is failing to remain focused on attracting more business.

\section{DATA AND METHODOLOGY}

The subject of analysis in this study is to determine how the concentration in the banking sector of the Republic of Serbia affects the efficiency of the banking sector of the Republic of Serbia. The starting hypothesis is: higher concentration in the banking sector of the Republic of Serbia contributes to the reduction of efficiency.

In this study, the methods of statistical analysis were: correlation and regression analysis. Using these methods it is possible to determine the nature of the connection, the significance of the connection and influence HHI on C/I ratio. 
For the purposes of methodological explanations and analysis, the data from the balance sheet and income statement which commercial banks deliver to the National Bank of Serbia have been used, for the period from 2008 to 2015.

\subsection{The results of research and discussion}

In the time period from 2008 to 2015 there was a decrease in the number of banks. At the end of 2008, in the Republic of Serbia, thirty-four commercial banks were operating, six of which were large, seventeen medium and eleven small ones ${ }^{2}$. The group of large banks, in that year, had $51.22 \%$ of the total assets of all commercial banks. Also, in that year, there were fourteen banks in majority domestic ownership (eight banks in majority state, six of them in majority privately owned), while twenty banks were with majority foreign ownership. At the end of the observed time period, or at the end of 2015, in the Republic of Serbia, thirty commercial banks operated, representing a decrease of $12 \%$ compared to the initial year. The structure of commercial banks consisted of six large banks with a share of $60.10 \%$ of the total assets of all commercial banks, twelve medium and twelve small banks. Of the total number of banks, seven banks were in majority domestic ownership (six of which were majority stateowned and majority privately owned), and twenty-three banks with majority foreign ownership.

In the observed period, there is a continuous increase in total assets of commercial banks. A decrease is only present in 2013, which is a consequence of decreasing the biggest key categories of assets, with the most prominent decrease in loans and advances. In terms of ownership structure of banks in the Republic of Serbia, foreign-owned banks dominate, whose shares in total assets are around $75 \%$ during each year of the period under consideration.

The results of the research on the concentration, according to the Herfindahl-Hirschman Index, show that the banking market of the Republic of Serbia is one of the fragmented markets with a large number of small uncompetitive banks.

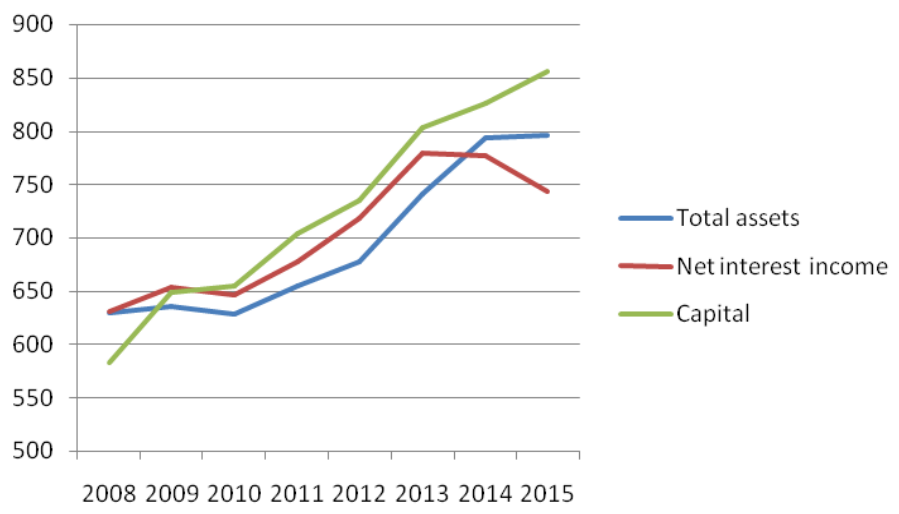

Chart 1 Movement of HHI values in the period from 2008 to 2015.

Source: Author's calculations based on data from commercial banks financial reports of the Republic of Serbia

\footnotetext{
${ }^{2}$ Small banks have assets of less than $1 \%$ of total assets of all banks, medium-sized banks have assets of more than $1 \%$ but less than $5 \%$ of the total assets of all banks, while large banks are banks with assets exceeding $5 \%$ of the total assets of all banks.
} 
Based on Chart 1, it can be seen that the Herfindahl-Hirschman Index has a maximum value for capital. Due to the growth of large banks, there has been an increase in the value of the Index. The Index value of the total assets of all banks rose from 629.58 at the end of 2008 to 796.38 at the end of 2015. Measured by the Index, the higher level of concentration is present in all variables. Also, the highest concentration level was recorded in the capital in 2015 and amounted to 855.34. For the observed period, it can be concluded, that the banking sector, from year to year, is characterized by a higher level of concentration.

In the analyzed period, increasing revenues and reducing costs can be seen, which had a positive impact on the bank efficiency measured by the cost to income ratio. The banking sector was the least effective in 2010 and 2012, which resulted in a considerable increase in costs.

By statistical analysis, correlation, the relationship was examined between the value of cost to income ratio and Herfindahl-Hirschman value Index for total assets, capital and net interest for the period from 2008 to 2015. The degree of quantitative agreement was $0.721 ;-0.715 ;-0.716$ respectively. The highest degree of linear correlation is between total assets and the level of efficiency, where Pearson's coefficient has a value of 0.043 which indicates a high degree of linear correlation between these two variables.

By applying the regression analysis of the cost to income ratio, which represents the dependent variable and Herfindahl-Hirschman Index for total assets (independent variable), the degree of influence of the independent variable on the dependent was examined. Unit increase in HHI of total assets affects the change in the value of cost to income ratio for the -0.721 . The regression model is statistically representative and based on it, it is possible to predict changes in cost to income ratio at HHI increase of total assets. In the regression model, it can be noted that it is possible to predict the movement of the dependent variable values based on the changes of the independent variable.

Table 2 Regression analysis

\begin{tabular}{|c|c|c|c|c|c|c|}
\hline \multirow[b]{2}{*}{ Model } & & \multicolumn{2}{|c|}{$\begin{array}{l}\text { Unstandardized } \\
\text { Coefficients }\end{array}$} & \multirow{2}{*}{$\begin{array}{c}\text { Standardized } \\
\text { Coefficients }\end{array}$} & \multirow[b]{2}{*}{$\mathrm{t}$} & \multirow[b]{2}{*}{ Sig. } \\
\hline & & $\mathrm{B}$ & Std. Error & & & \\
\hline \multirow[t]{2}{*}{1} & (Constant) & 1.158 & .331 & & 3.496 & .013 \\
\hline & $\mathrm{HHI}_{\text {total assets }}$ & -.001 & .000 & -.721 & -2.551 & .043 \\
\hline
\end{tabular}

\section{CONCLUSION}

Concentration in the banking sector is generally horizontal, which means that there is joining of market participants that offer substituent products. The main motives because of which concentration appears are: ratio economy, diversification of credit risk, improving organizational efficiency, lower financing costs and scale economy. However, noncompetitive market structures, especially monopolies, generate adverse effects on social welfare. For this reason, it is necessary to create adequate antitrust politics and to establish an effective antitrust institution. The politics of competition protection contributes to the achievement of effective competition that is a prerequisite for economic and social progress (Stojanović \& Kostić, 2013). 
To demonstrate the state of concentration in the banking sector of the Republic of Serbia, a statistical analysis of the variables has been conducted: total assets, capital and net interest income. Concentration analysis was performed using market Herfindahl-Hirschman Index. The highest level of concentration measured by the Herfindahl-Hirschman Index is in the capital, while the lowest concentration level achieved is in net interest income. In general, the banking sector of the Republic of Serbia can be characterized as fragmented, and the degree of concentration increases from year to year.

How the concentration and efficiency of the banking sector of the Republic of Serbia will change in the future depends on many external and internal factors on the state of the global market, new regulatory requirements and internal strategies of individual banks. Thereby, it should be borne in mind that prevention of monopoly in the banking sector should be imperative.

\section{REFERENCES}

Apergis, N. \& Alevizopoulou, E. (2011). Bank Efficiency: Evidence from a Panel of European Banks. Panoeconomicus, 3, 329-341.

Barth, J. R., Caprio, G. Jr. \& Levine, R. (2001). The Regulation and Supervision of Banks around the World: A New Database, Retrieved from: http://citeseerx.ist.psu.edu/viewdoc/download?doi=10.1.1.198.7983\&rep= rep1\&type=pdf, Accessed on: 23 August 2016.

Begović, B., Bukvić, R., Mijatović, B., Paunović, M., Sepi, R. \& Hiber, D. (2002). Antimonopolska politika u SR Jugoslaviji [Antimonopoly Policy in FR Yugoslavia]. Centar za liberalno - demokratske studije. Beograd.

Berger, A. N. (2007). International Comparisons of Banking Efficiency. Financial Markets, Institutions and Instruments, 16, 119-144.

Bikker, J. A. \& Groeneveld, J. M. (1998). Competition and Concentration in the EU Banking Industry. Research Series Supervision no. 8. De Nederlandsche Bank.

Claessens, S., Demirguec-Kunt, A. \& Huizinga, H. (2000). How Does Foreign Entry Affect Domestic Banking Markets?, Retrieved from: http://siteresources.worldbank.org/DEC/Resources/84797-1114437274304/final.pdf, Accessed on: 30 August 2016.

Claessens, S. \& Laeven, L. (2003). What Drives Bank Competition? Some International Evidence. Policy Research Working Paper 3113. The World Bank, Financial Sector Operations and policy Department.

Demirguec-Kunt, A., Laeven, L. \& Levine, R. (2003). Regulations, Market Structure, Institutions, and the Cost of Financial Intermediation. Working Paper 9890. National Bureau of Economic Research.

Demsetz, H. (1973). Industry Structure, Market Rivalry, and Public Policy. Journal of Law and Economics, 16, 1-9.

Drake, L. \& Hall, M. J. B. (2003). Efficiency in Japanese banking: An empirical analysis. Journal of Banking \& Finance, 27, 891-917.

Ferreira, C. (2012). Bank efficiency, market concentration and economic growth in European Union. Working Papers ISSN 0874-4548. School of Economics and Management, Technical University of Lisbon.

Ljumović, I., Marinković, S. \& Pejović, B. (2011). Efikasnost i profitabilnost banaka - koliko su koncepti međusobno isključivi? [Efficiency and Profitability of Banks - How Many Concepts are Mutually Exclusive?]. Retrieved from: http://scindeks-clanci.ceon.rs/data/pdf/0350-0373/2011/0350-03731104043L.pdf, Accessed on: 20 September 2016.

Marinković, M. (2012). Nivo koncentracije u bankarskom sektoru Srbije [The Level of Concentration in the Banking Sector of Serbia]. Makroekonomske analize i trendovi, Novembar, 39-40.

Petrović, S. \& Ružić, T. (2001). Koncentracija banaka [The Concentration of Banks]. Hrvatska pravna revija, br. 9/2001.

Stojanović, B., Stanišić, T. \& Veličković, M. (2010). Problem zaštite konkurencije u trgovini na malo u Srbiji [The Problem of Protecting Competition in Retail in Serbia]. Škola biznisa, 3/2010, $57-66$.

Stojanović, B. \& Kostić, M. (2013). Competition condition and the impact of market share on firms' profitability. Ekonomika preduzeća (pp.325-338). YU ISSN 0353-433 X, Serbian Association of Economists Journal of Business Economics and Management. 


\section{UTICAJ KONCENTRACIJE NA EFIKASNOST BANKARSKOG SEKTORA REPUBLIKE SRBIJE}

Za kvalitetnu analizu uticaja koncentracije specifične delatnosti, kao što je bankarstvo, na ostala kretanja u bankarskom sektoru neophodno je njeno precizno merenje. Usled transformacije bankarskog sektora u Republici Srbiji, u relativno kratkom vremenskom intervalu, došlo je do značajnog smanjenja broja banaka i povećanja koncentracije. Sa druge strane, ključni faktor za opstanak banaka na tržištu postala je efikasnost poslovanja. U radu je koncentracija merena Herfindahl-Hirscham-ovim indeksom, dok je stepen efikasnosti određen količnikom troškova $i$ prihoda (cost to income ratio). Pomoću linearne korelacije i regresione analize ispitana je povezanost između stepena koncentracije i nivoa efikasnosti bankarskog sektora Republike Srbije u vremenskom intervalu od 2008. do 2015. godine, kojima je potvrđeno postojanje jake veze između ovih varijabli.

Ključne reči: koncentracija, efikasnost, bankarski sektor, Republika Srbija 